\title{
Genetic Analysis of Some Quantitative Traits in Hybrid Rice with Utilizing Cytoplasmic Genetic Male Sterility System
}

\author{
G. B. Anis, M. M. Kamara ${ }^{* \#}$ and M. A. El-Sayed \\ Rice Res. \& Training Center (RRTC), Field Crops Res. Inst., \\ ARC, Cairo and *Agronomy Dept., Faculty of Agriculture, \\ Kafrelsheikh Univ., Kafrelsheikh, Egypt.
}

\begin{abstract}
7 HE PRESENT investigation was conducted to study the genetic variance components, heritability, heterosis and combining ability in relation to identifying desirable parents and hybrids for hybrid rice breeding program. Three cytoplasmic male sterile (CMS) lines and five restorers (testers) were crossed in line $\times$ tester scheme in 2014 growing season. The resulted $15 \mathrm{~F}_{1}$ hybrids along with their eight parents, three maintainers lines and one standard check variety (Giza 178) were evaluated in a randomized complete block design (RCBD) with three replications at Rice Research and Training Center (RRTC) Farm, Sakha, Kafrelsheikh, Egypt during 2015 growing season. Data were recorded on eight quantitative traits, i.e. days to heading, plant height, panicle length, 1000-grain weight, panicle weight, the number of panicles/plant, spikelet fertility percentage and grain yield. The results showed that, the mean squares due to genotypes, parents, crosses and parents $v s$. crosses were highly significant for all the studied traits. Highly significant differences were detected among lines, testers and line $\times$ tester for all the studied traits. The nonadditive genetic variance played an effective role in the inheritance of all studied traits, except days to heading, plant height and panicle weight. Heritability estimates in the broad sense $\left(\mathrm{h}_{\mathrm{b}}^{2} \%\right)$ were high for all the studied traits. However, heritability estimates in the narrow sense $\left(\mathrm{h}_{\mathrm{n}}^{2} \%\right)$ were moderate to high for some traits. Relatively high genetic advance coupled with high heritability estimates were detected for panicle weight. Highly significant and positive estimates of heterosis over better parent and the check variety (Giza 178) were detected in all the $F_{1}$ hybrids for the grain yield trait. The CMS line G46A and the restorers GZ9399 and PR6 were the best general combiners for grain yield. The hybrid combinations viz., IR69625A $\times$ Giza179, IR69625A $\times$ PR5, IR70368A × GZ9399, IR70368A $\times$ WTR1 and G46A $\times$ PR5 had the best SCA effects for grain yield and some of its components.
\end{abstract}

Keywords: Rice, Cytoplasmic male sterility, Combining ability, Heterosis

Rice (Oryza sativa L.) is the main food crop for over one-half of the world's human population (Yuan, 2014). Rice plays a significant role in Egypt strategy for sustaining the food self-sufficiency and for increasing the export. By the year

"Corresponding author email: dr_wagid1212@yahoo.com 
2030, the world population is expected to reach approximately 8 billion (Fageria, 2007). Hence, it will be necessary to increase rice production by $40 \%$ to meet the food needs of a growing world population. To meet this challenge, the use of hybrid rice technology would offer an alternative to increase further the yield potential of rice by exploiting the genetic expression of hybrid vigor (heterosis). Currently, the cytoplasmic male sterility (CMS) system, commonly known as the three-line system is the most widely used system for commercial exploitation of hybrid rice technology. This system includes three different lines, namely A (CMS line), B (maintainer line) and R (restorer line). Hybrid rice based on CMS system leading to increase grain yield by more than $20 \%$ relative to the best traditional rice cultivars (Cheng et al., 2007 and Yuan, 2014). The exploitation of heterosis seems to be one of the options for making further increase in rice yield potential. The extent of heterosis has been estimated as a superiority of the hybrids over their mid parent (relative heterosis), superiority of the hybrids over better parent (heterobeltiosis) and superior over standard check variety (standard/economic heterosis). Favorable and significant heterosis for grain yield and its components in rice have been reported by several workers ( $\mathrm{Li}$ et al., 2002; Alam et al., 2004; Malini et al., 2006 and Anis, 2013).

The success of any breeding program greatly depends upon sensible choice of parents for hybridization and the gene action of different economic traits. The line $\times$ tester analysis method is widely used to determine general (GCA) and specific combining ability (SCA) effects and helps in selecting favorable parents and hybrids (Kempthorne, 1957). The GCA is typically associated with additive gene effects and is theoretically fixable. While, SCA is primarily attributed to non-additive gene action (dominance or epistasis) and is non-fixable. Both additive and non-additive gene effects have been reported to be important in the genetic expression of many rice traits including grain yield (Rita \& Motiramani, 2005 and El-Degwy, 2013). However, the non-additive gene action was predominant for days to heading, number of panicles/ plant, panicle weight, panicle length and grain yield (Abd El-Hadi et al., 2013 and Hasan et al., 2015). While, the additive gene action appeared to be more important in the genetic expression of rice grain yield and some of its contributing traits (Hassan et al., 2012). The present investigation aimed to study the genetic variance components, heritability, heterosis and combining ability in relation to identify desirable parents and hybrids for hybrid rice breeding program.

\section{Materials and Methods}

The present investigation was carried out at the Experimental Farm of the Rice Research and Training Center (RRTC), Sakha, Kafrelsheikh, Egypt, during the two successive rice growing seasons 2014 and 2015. Three CMS lines namely; IR69625A, IR70368A and G46A were used as female lines and crossed through line $\times$ tester mating design with five testers; Giza 179, GZ9399, PR5, PR6 and Weed Tolerant Rice 1 to produce $15 \mathrm{~F}_{1}$ hybrids during 2014 growing season. The cytoplasmic source, parentage and origin of the parental lines are presented in Table 1.

Egypt. J. Agron. 38, No. 2 (2016) 
TABLE 1. The cytoplasmic source, parentage and origin of the parental lines.

\begin{tabular}{|l|c|c|}
\hline \multicolumn{1}{|c|}{ Genotypes } & Cytoplasmic source/ parentage & Origin \\
\hline CMS Lines: & Wild Abortive (WA) & IRRI \\
IR69625 A & Wild Abortive (WA) & IRRI \\
IR70368A & Gambica & China \\
G46 A & & Egypt \\
Restorers: & GZ1368-5-S-5/GZ6296-12-1-2-1-1 & Egypt \\
Giza 179 & Giza 178/IR65844-29-1-3-1-2 & Egypt \\
GZ9399 & Giza 178/GZ6296-12-1-2-1-1 & Egypt \\
PR5 & Giza 178/GZ6296-12-1-2-1-1 & China \\
PR6 & Exotic line & \\
WTR1* &
\end{tabular}

*WTR1: Weed Tolerant Rice 1

The resultant $15 \mathrm{~F}_{1}$ hybrids along with their eight parents, three maintainer lines; IR69625B, IR70368B and G46B and one standard check variety (Giza 178) were evaluated in a randomized complete block design (RCBD) with three replications during 2015 growing season. Thirty day old seedlings of each genotype were transplanted in a single seedling per hill in the experimental plots. Each plot consisted of 7 rows, $5 \mathrm{~m}$ length with the spacing of $20 \times 20 \mathrm{~cm}$. The soil was clayey in texture with $\mathrm{pH}(8.22), \mathrm{EC}\left(3.05 \mathrm{ds} \mathrm{m}^{-1}\right), 1.5 \%$ total organic matter, $0.12 \%$ total nitrogen $(\mathrm{N})$, $12.6 \mathrm{mg} \mathrm{kg}{ }^{-1}$ available phosphorus (P) and $366 \mathrm{mg} \mathrm{kg}^{-1}$ exchangeable potassium (K). All agronomic practices such as fertilization, irrigation, weeds and pests control were done as recommended with rice crop during growing seasons of the study. Data were collected on days to heading (day), plant height $(\mathrm{cm})$, panicle length $(\mathrm{cm}), 1000$-grain weight $(\mathrm{g})$, panicle weight $(\mathrm{g})$, number of panicles/plant, spikelet fertility (\%) and grain yield ton per hectare ( $\mathrm{t} / \mathrm{ha})$, according to the standard evaluation system for rice, IRRI (1996). All the measurements of the CMS lines were recorded for their iso-genic maintainer lines. The obtained data were subjected to line $\times$ tester analysis to estimate general and specific combining ability effects and variances according to Kempthorne (1957). Heritability was estimated as stated by Borton \& Devan (1953). The expected genetic advance from selection $(\Delta \mathrm{g})$ was calculated as stated by Johnson et al. (1955).

The percent increase or decrease of $\mathrm{F}_{1}$ hybrids over better parent as well as standard check variety (Giza 178) was calculated to estimate heterotic effects for all the studied traits (Fonseca \& Patterson, 1968)

\section{Results and Discussion}

\section{Test of significance}

The analysis of variance (Table 2) showed highly significant mean squares due to the genotypes for all the traits studied, indicating large variation among the tested genotypes for such traits. The mean squares of the genotypes were further portioned into parents, crosses and parents vs. crosses, the mean squares due to such partitions were highly significant for all the measured traits. The significant of parents $v s$. crosses mean squares indicated prevalence of heterosis for all traits. The variations among crosses were partitioned into lines, testers and line $\times$ tester. Highly significant differences were detected among lines, testers and line $\times$ tester for all the studied traits.

Egypt. J. Agron. 38, No. 2 (2016) 


\begin{tabular}{|c|c|c|c|c|c|c|c|c|c|c|c|}
\hline 窇 & 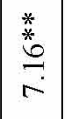 & $\begin{array}{l}\stackrel{*}{*} \\
\stackrel{*}{a} \\
i \\
i\end{array}$ & $\begin{array}{l}\frac{*}{*} \\
\stackrel{*}{0} \\
0 \\
0\end{array}$ & $\begin{array}{l}* \\
\stackrel{*}{*} \\
\hat{\sigma} \\
\stackrel{0}{9}\end{array}$ & 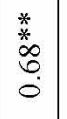 & $\stackrel{\stackrel{*}{*}}{\stackrel{*}{\Xi}}$ & $\begin{array}{l}* \\
* \\
\infty \\
\stackrel{*}{0} \\
0\end{array}$ & $\begin{array}{c}\tilde{0} \\
0\end{array}$ & $\begin{array}{l}0 \\
0 \\
0\end{array}$ & $\stackrel{8}{8}$ & $\stackrel{m}{o}$ \\
\hline 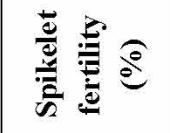 & 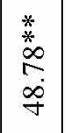 & 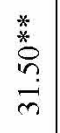 & 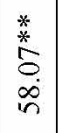 & $\begin{array}{l}\frac{*}{*} \\
\stackrel{0}{0} \\
\stackrel{m}{2}\end{array}$ & $\frac{\stackrel{*}{*}}{\stackrel{5}{m}}$ & 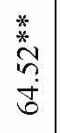 & $\begin{array}{l}* \\
* \\
0 \\
0 \\
8 \\
8\end{array}$ & $\exists$ & $\left|\begin{array}{c}m \\
\tilde{m} \\
0\end{array}\right|$ & $\begin{array}{l}\hat{0} \\
\varrho\end{array}$ & $\begin{array}{l}0 \\
0 \\
0\end{array}$ \\
\hline 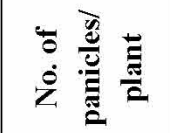 & $\mid$\begin{tabular}{l}
$*$ \\
\multirow{2}{*}{} \\
8 \\
0 \\
0
\end{tabular} & $\begin{array}{l}\underset{*}{*} \\
\stackrel{5}{6} \\
\infty \\
-\end{array}$ & $\begin{array}{l}* \\
* \\
\stackrel{*}{0} \\
\infty \\
0\end{array}$ & $\begin{array}{l}* \\
* \\
0 \\
\infty \\
\end{array}$ & 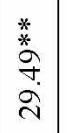 & 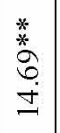 & $\begin{array}{l}\stackrel{*}{*} \\
\stackrel{*}{\sim} \\
\stackrel{\sim}{+}\end{array}$ & $\stackrel{n}{\vdots}$ & $\left|\begin{array}{c}\infty \\
0 \\
0\end{array}\right|$ & $\stackrel{\bullet}{=}$ & $\stackrel{m}{0}$ \\
\hline 莺 & \begin{tabular}{|l|}
$\stackrel{*}{*}$ \\
$\stackrel{2}{\alpha}$ \\
$\dot{\sigma}$
\end{tabular} & $\begin{array}{l}\stackrel{*}{*} \\
\stackrel{n}{n} \\
\stackrel{n}{-}\end{array}$ & $\begin{array}{l}\stackrel{*}{*} \\
\overrightarrow{5} \\
i\end{array}$ & $\begin{array}{l}\stackrel{*}{*} \\
\stackrel{\vec{d}}{\sigma} \\
\vec{b}\end{array}$ & $\frac{\frac{*}{*}}{\stackrel{5}{a}}$ & \begin{tabular}{l|}
$\stackrel{*}{*}$ \\
$\stackrel{*}{2}$ \\
$\stackrel{2}{+}$ \\
$\stackrel{+}{*}$
\end{tabular} & $\stackrel{*}{\stackrel{*}{*}}$ & $\begin{array}{l}8 \\
0\end{array}$ & $\mid \begin{array}{l}m \\
0\end{array}$ & o. & $\stackrel{m}{+}$ \\
\hline 言言言 & 莩 & $\begin{array}{c}\stackrel{*}{*} \\
\stackrel{*}{*} \\
\stackrel{6}{-}\end{array}$ & 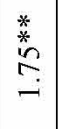 & $\begin{array}{l}\underset{*}{*} \\
\infty \\
i \\
-i\end{array}$ & 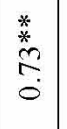 & 苝 & $\begin{array}{l}\stackrel{*}{*} \\
\stackrel{*}{*} \\
\stackrel{0}{0} \\
0\end{array}$ & $\stackrel{8}{\circ}$ & $\begin{array}{l}0 \\
0 \\
0\end{array}$ & $\frac{\overrightarrow{0}}{0}$ & $\bar{m}$ \\
\hline 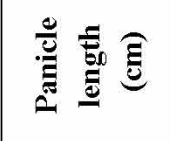 & $\mid \begin{array}{c}* \\
\stackrel{*}{*} \\
i \\
\infty \\
\infty\end{array}$ & 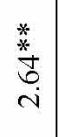 & \begin{tabular}{l}
$\underset{*}{*}$ \\
\multirow{2}{*}{} \\
in \\
.
\end{tabular} & 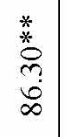 & $\begin{array}{l}\stackrel{*}{*} \\
\stackrel{2}{R} \\
\infty \\
\end{array}$ & $\begin{array}{l}\stackrel{*}{*} \\
\stackrel{*}{0} \\
\stackrel{0}{0}\end{array}$ & $\begin{array}{l}\stackrel{*}{*} \\
\stackrel{*}{\infty} \\
\stackrel{\infty}{-}\end{array}$ & ગุ & ণิ & in & \begin{tabular}{l}
0 \\
\hdashline \\
0
\end{tabular} \\
\hline 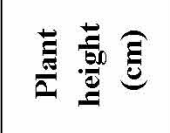 & 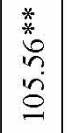 & $\begin{array}{l}* \\
* \\
\infty \\
\infty \\
\infty \\
\infty\end{array}$ & $\begin{array}{c}\stackrel{*}{*} \\
\stackrel{m}{m} \\
\infty\end{array}$ & 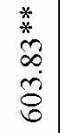 & 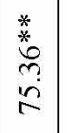 & $\begin{array}{l}\frac{\vec{*}}{*} \\
\infty \\
+ \\
\infty \\
\sim\end{array}$ & $\begin{array}{l}\stackrel{*}{*} \\
\stackrel{*}{ \pm} \\
\stackrel{ \pm}{ \pm}\end{array}$ & $\underset{\sim}{\mathcal{F}}$ & $\begin{array}{l}\tilde{I} \\
\underset{\gamma}{*}\end{array}$ & $\begin{array}{l}: \\
\dot{m}\end{array}$ & $\stackrel{\circ}{=}$ \\
\hline 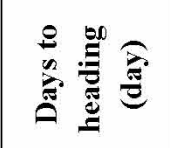 & 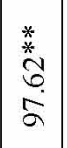 & $\begin{array}{l}\text { *. } \\
0 \\
0 \\
19 \\
\vdots \\
-1\end{array}$ & $\begin{array}{c}\underset{*}{*} \\
\stackrel{0}{\infty} \\
\infty \\
\infty\end{array}$ & 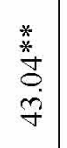 & 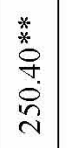 & 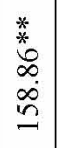 & $\begin{array}{l}* \\
* \\
\infty \\
\infty \\
\stackrel{0}{0}\end{array}$ & $\begin{array}{l}\infty \\
i n \\
0\end{array}$ & $\underset{\forall}{\stackrel{\Xi}{+}}$ & $\stackrel{m}{m}$ & $\underset{-}{\beth}$ \\
\hline$\stackrel{5}{-1}$ & $\approx$ & $r$ & \pm & - & $N$ & + & $\infty$ & $\exists$ & . & ' & \\
\hline 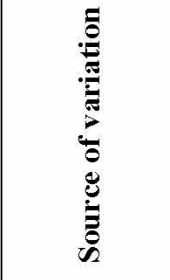 & $\mid \begin{array}{l}0 \\
0 \\
0 \\
0 \\
0 \\
0 \\
0 \\
0 \\
0\end{array}$ & 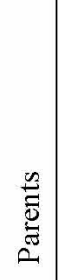 & 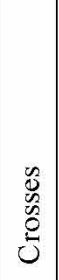 & 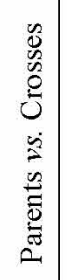 & 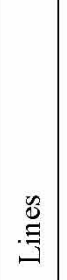 & 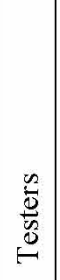 & 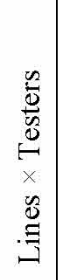 & 它 & $\left|\begin{array}{c}\overleftarrow{\delta} \\
0 \\
0\end{array}\right|$ & 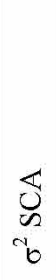 & 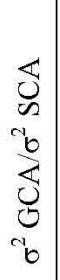 \\
\hline
\end{tabular}

Egypt. J. Agron. 38, No. 2 (2016) 
The comparative estimates of general $\left(\sigma^{2} \mathrm{GCA}\right)$ and specific combining ability $\left(\sigma^{2} \mathrm{SCA}\right)$ variances showed that the value of the $\sigma^{2} \mathrm{GCA}$ variance was less than the value of $\sigma^{2} \mathrm{SCA}$ variance. Moreover, the ratio of $\sigma^{2} \mathrm{GCA} / \sigma^{2} \mathrm{SCA}$ was less than unity for all studied traits, except days to heading, plant height and panicle weight. These results indicated that the non-additive gene effects played a major role in the genetic expression of these traits, while the inheritance of the excepted traits were chiefly controlled by additive gene effects (Table 3 ). These results are in general agreement with those previously reported by Satyanarayana $e t$ al. (2000), Rita \& Motiramani (2005), Venkatesan et al. (2007), Dalvi \& Patel (2009), Saidaiah et al. (2010), Shyam et al. (2012), Abd El-Hadi et al. (2013) and Hasan et al. (2015).

\section{Mean performance}

Mean performance of the parents and $F_{1}$ hybrid combinations for all the studied traits are presented in Table 3 . Mean performance of the studied traits varied from cross to another. For days to heading, the CMS line G46A and new promising line GZ9399 were the earliest in heading date as they recorded the lowest value of 92.3 and 92.7 days, respectively. While, the CMS line IR69625A was the latest parent in heading date and recorded the highest value of 107.0 day. The hybrid combinations $(\mathrm{G} 46 \mathrm{~A} \times \mathrm{PR} 6),(\mathrm{G} 46 \mathrm{~A} \times \mathrm{GZ9399})$ and $(\mathrm{G} 46 \mathrm{~A} \times \mathrm{PR} 5)$ gave the lowest mean values of $91.00,92.30$ and 93.00 days, respectively. While, the hybrids (IR69625A $\times$ WTR1), $($ IR70368A $\times$ WTR1) and $($ G46A $\times$ WTR1) gave the highest mean values of 108.7, 106.7 and 106.3 days, respectively.

For plant height, the results showed that among the parents the maximum plant height $(112.3 \mathrm{~cm})$ was recorded in the parent WTR1, and the minimum plant height $(96.0 \mathrm{~cm})$ was recorded in the parent $\mathrm{G} 46 \mathrm{~A}$. Among the $\mathrm{F}_{1}$ hybrids, the maximum plant height $(120.3 \mathrm{~cm})$ was recorded in the cross IR69625A $\times$ WTR1. While, the minimum plant height $(100.3 \mathrm{~cm})$ was obtained in case of G46A $\times$ GZ9399. Large variation among the tested rice genotypes were detected for panicle length. Among the parents, WTR1 recorded the highest panicle length $(26.9 \mathrm{~cm})$, while GZ9399 recorded the lowest value $(23.9 \mathrm{~cm})$. On the other hand, such estimates were maximized in the hybrid G46A $\times$ WTR1 (31.3 $\mathrm{cm})$ followed by G46A $\times$ PR6 $(28.7 \mathrm{~cm})$ and G46A $\times$ PR5 $(27.7 \mathrm{~cm})$. Among the tested parents, WTR1 recorded the heaviest 1000-grain weight $(29.3 \mathrm{~g})$ followed by PR6 (28.2 g). While, GZ9399 exhibited the minimum value (26.9 g). In $F_{1}$ hybrids, the highest 1000 -grain weight $(29.8 \mathrm{~g})$ was observed in the cross IR69625A $\times$ WTR1, followed by IR70368A $\times$ WTR1 $(29.3 \mathrm{~g})$ while, the lowest 1000 -grain weight $(27.1 \mathrm{~g})$ was observed in the cross IR70368 A $\times$ GZ9399.

As shown in Table 3, among the parents, WTR1was the most desirable hybrid for panicle weight $(6.4 \mathrm{~g})$ followed by PR6 $(5.1 \mathrm{~g})$. In $\mathrm{F}_{1}$ hybrids, the highest panicle weight $(8.60 \mathrm{~g})$ was obtained in the cross G46A $\times$ WTR1 followed by G46A $\times$ PR6 rice hybrid $(7.9 \mathrm{~g})$, while the lowest weight of panicle $(5.5 \mathrm{~g})$ was recorded in case of IR70368A $\times$ Giza 179. 


\begin{tabular}{|c|c|c|c|c|c|c|}
\hline 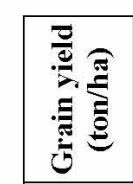 & $\begin{array}{ccc}0 & 0 & \overrightarrow{1} \\
0 & \infty & \infty\end{array}$ & $\hat{\ominus} \stackrel{\infty}{\circ} \stackrel{\circ}{\circ} \vec{\varrho} \stackrel{0}{\circ}$ & 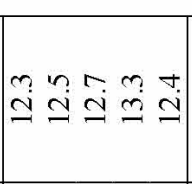 & 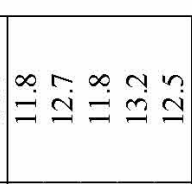 & 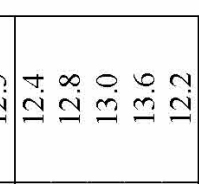 & $\mid$\begin{tabular}{lll}
0 & 0 \\
\hdashline & 0 & 0 \\
0 & 0
\end{tabular} \\
\hline 这 & $\begin{array}{lll}m & \bar{d} & n \\
\sigma & \infty & 0\end{array}$ & 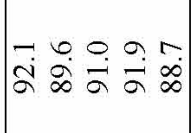 & 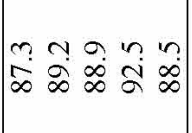 & 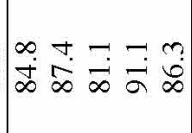 & 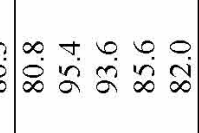 & $\stackrel{\substack{ \pm-i}}{-i}$ \\
\hline 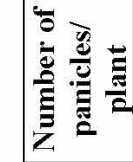 & 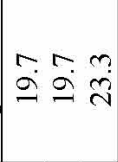 & 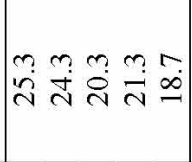 & 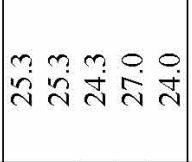 & 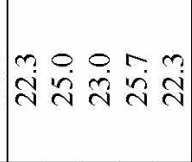 & 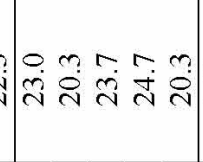 & $\stackrel{7}{=}$ \\
\hline 递司 & 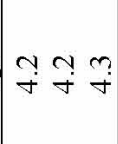 & 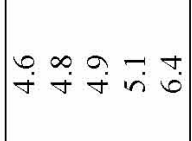 & in in 80 ? & 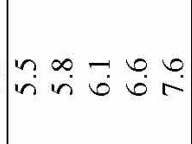 & 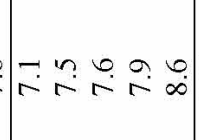 & 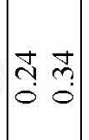 \\
\hline 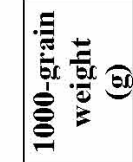 & 돈동 & 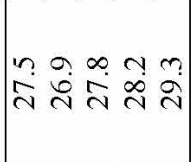 & 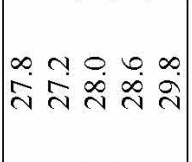 & 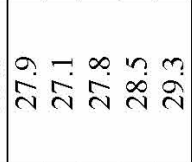 & 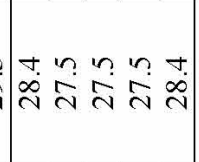 & 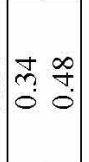 \\
\hline 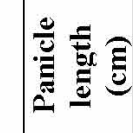 & $\begin{array}{lll}0 & \infty & 0 \\
& \dot{\sim} & \dot{d}\end{array}$ & 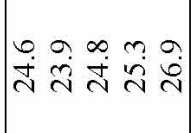 & 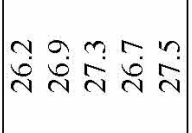 & 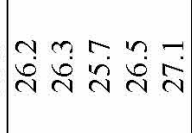 & 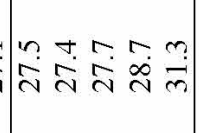 & $\left(\begin{array}{ll}0 & 2 \\
0 & 0 \\
0 & 0\end{array}\right.$ \\
\hline 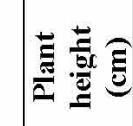 & 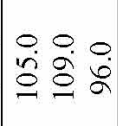 & 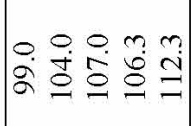 & 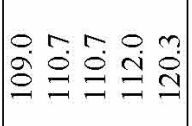 & 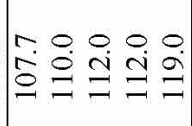 & 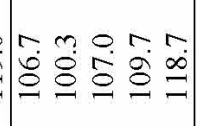 & 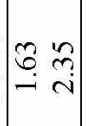 \\
\hline 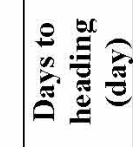 & 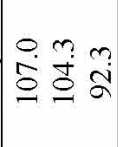 & 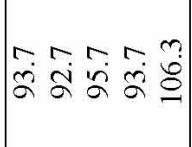 & 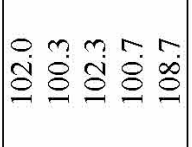 & 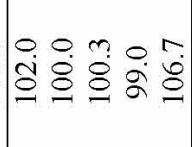 & 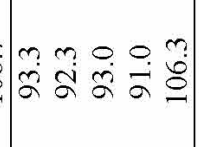 & $\stackrel{n}{2} \cdot \vec{n}$ \\
\hline \multirow[t]{2}{*}{ : } & 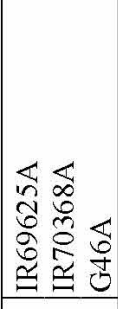 & 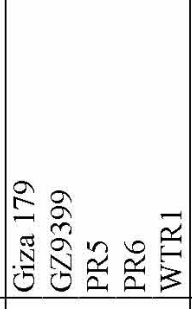 & 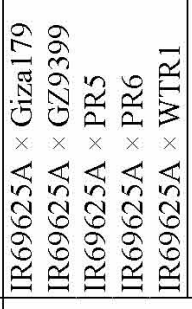 & 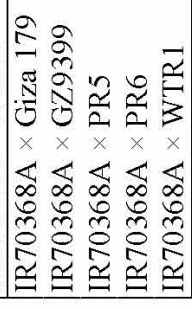 & 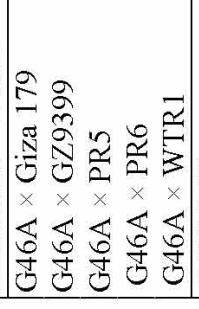 & 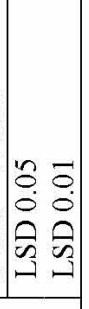 \\
\hline & $<\stackrel{\mathscr{\Xi}}{\Xi}$ & $\simeq \stackrel{\mathscr{v}}{\Xi}$ & & 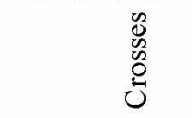 & & \\
\hline
\end{tabular}

Egypt. J. Agron. 38, No. 2 (2016) 
Rice genotypes were significantly varied in their number of panicles/plant. Giza 179 rice cultivar recorded the most desirable estimates (25.3) compared with the other parents. While, such estimates were minimized in case of WTR1 (18.7). Among the $F_{1}$ hybrid combinations, the maximum number of panicles (27.0 panicle) was noted in the cross combination of IR69625A $\times$ PR6 followed by IR70368A $\times$ PR6 with a value of 25.70 . While the lowest number of panicles (20.3) was detected in case of the crosses G46A $\times$ GZ9399 and G46A $\times$ WTR1. Rice genotypes differed from each other in spikelet fertility percentage. Such estimates ranged from (80.8\%) for the cross G46A $\times$ Giza 179 to (95.4\%) for the cross G46A $\times$ GZ9399. As shown in Table 3, compared with the other parents, GZ9399 recorded the highest grain yield (10.8 t/ha). While, G46B exhibited the lowest grain yield $\left(8.4 \mathrm{t} / \mathrm{ha}\right.$ ). In $\mathrm{F}_{1}$ hybrids, the cross G46A $\times$ PR6 gave the highest mean value $(13.6 \mathrm{t} / \mathrm{ha})$ followed by the cross IR69625A $\times$ PR6 and IR70368A $\times$ PR6 with average grain yield of 13.3 and $13.2 \mathrm{t} / \mathrm{ha}$, respectively. However, the two crosses IR70368A $\times$ Giza 179 and IR70368A $\times$ PR5 recorded the lowest mean values of grain yield (11.8 t/ha).

\section{General combining ability (GCA) effects}

The selection of parents with good GCA effects is a prime requisite for a successful breeding program especially hybrid breeding. Estimates of GCA effects of individual parent for each trait are shown in Table 4. High positive estimates of GCA effects are desirable for all studied traits, except days to heading and plant height which negative estimates are favorable. The results revealed that the CMS line IR69625A showed highly significant positive GCA effects for 1000-grain weight, number of panicles/plant and spikelet fertility percentage. Meanwhile, the CMS line IR70368A expressed either significant undesirable or insignificant GCA effects for all the studied traits. The CMS line G46A gave highly significant negative GCA effects for days to heading and plant height. Also, it showed highly significant positive GCA effects for panicle length, panicle weight and grain yield. This line could be considered as a good combiner for earliness, dwarfness and high grain yield. Similar results were reported by El-Degwy (2013).

Regarding to the testers or restorers, Giza 179 and PR5 had highly significant negative GCA effects for days to heading and plant height, indicating that these testers could be considered as excellent combiners for earliness and short stature. Furthermore, GZ9399 was found to be good general combiner for earliness, short stature, spikelet fertility and grain yield. The parent PR6 showed highly significant negative GCA effects for days to heading and also showed highly significant positive GCA effects for panicle weight, number of panicles/plant, spikelet fertility percentage and grain yield. This parental tester could be considered as a good combiner for earliness, grain yield and most of its components. The WTR1 showed highly significant positive GCA effects for panicle length, 1000-grain weight and panicle weight and considered as a good combiner for these traits. Such results indicated that these parents had favorable

Egypt. J. Agron. 38, No. 2 (2016) 


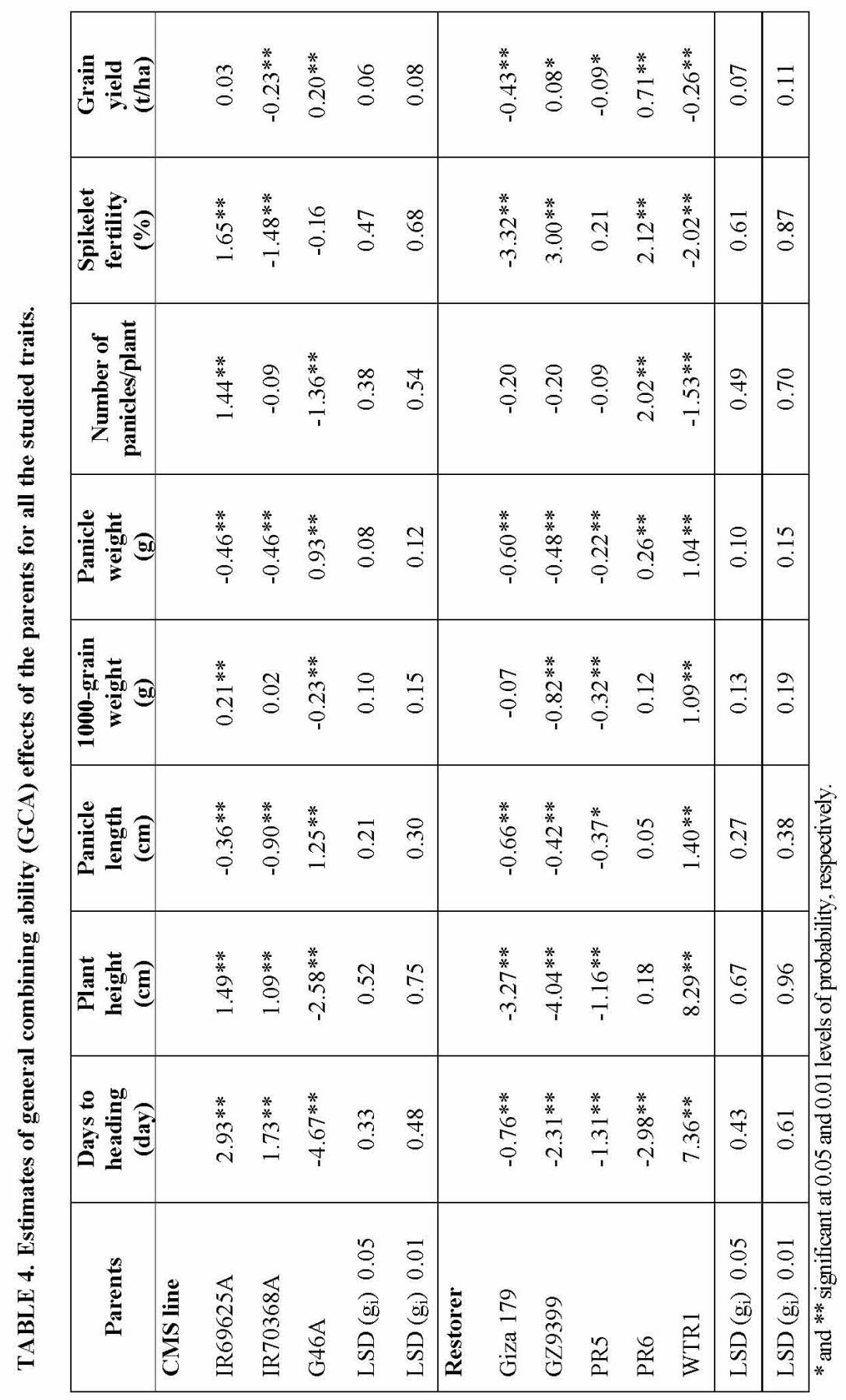

Egypt. J. Agron. 38, No. 2 (2016) 
genes and that improvement in respective traits may be attained if they are incorporated in rice hybridization program. It is obvious that none of the parents were found to be good general combiner for all studied traits, as the combining ability effects were not consistent for all the yield and yield contributing traits simultaneously. Similar findings were also reported by Sarker (2001), Rosamma \& Vijayakumar (2005), Petchiammal \& Kumar (2007), Saleem et al. (2010), Abd El-Hadi et al. (2013) and Hasan et al. (2015).

Specific combining ability (SCA) effects

As shown in Table 5, five hybrid combinations IR69625A $\times$ WTR1, IR70368A $\times$ WTR1, G46A $\times$ Giza 179, G46A $\times$ PR5 and G46A $\times$ PR6 had significant or highly significant negative SCA effects for days to heading towards earliness. For plant height, the hybrids IR70368A $\times$ Giza179, IR70368A $\times$ WTR1 and G46A $\times$ GZ9399 exhibited either significant or highly significant negative SCA effects, indicating that they are good specific combiners for short plant stature. Only two crosses IR69625A $\times$ PR5 and G46A $\times$ WTR1 showed highly significant and positive SCA effects for panicle length. The best specific combiners for 1000 -grain weight were the crosses IR69625A $\times$ WTR1, IR70368A $\times$ PR6, G46A $\times$ Giza179 and G46A $\times$ GZ9399. For panicle weight, three crosses IR69625A $\times$ Giza179, IR70368A $\times$ WTR1 and G46A $\times$ GZ9399 detected favorable significant or highly significant SCA effects for this trait. Out of 15 hybrid combinations only two crosses (IR70368A $\times$ GZ9399 and G46A $\times$ PR5) had highly significant positive SCA effects for number of panicles/plant. Regarding spikelet fertility \%, eight hybrid combinations manifested significant or highly significant positive (desirable) SCA effects for this trait. The hybrid G46A $\times$ PR5 had the highest desirable SCA effects. These results were similar to those obtained by Panwar (2005) and El- Degwy (2013). With respect to grain yield, estimates of SCA effects showed that the five crosses, i.e. IR69625A $\times$ Giza179, IR69625A $\times$ PR5, IR70368A × GZ9399, IR70368A $\times$ WTR1 and G46A $\times$ PR5 gave positive and significant or highly significant SCA effects, indicating that these crosses are the best combinations for improving grain yield.

Generally, crosses showing high SCA effects for grain yield involved parents of high or low GCA value. It is notable that the crosses that showed high SCA effects for grain yield also showed high SCA effects for one or more traits of yield components. For example, the cross G46A $\times$ PR5 which showed high SCA effects for grain yield also showed high SCA effects for number of panicles/plant and fertility percentage. Such results were in agreement with those reported by Sreeramachandra et al. (2000), Sandhyakishore et al. (2011), El- Degwy (2013) and Hasan et al. (2015). 


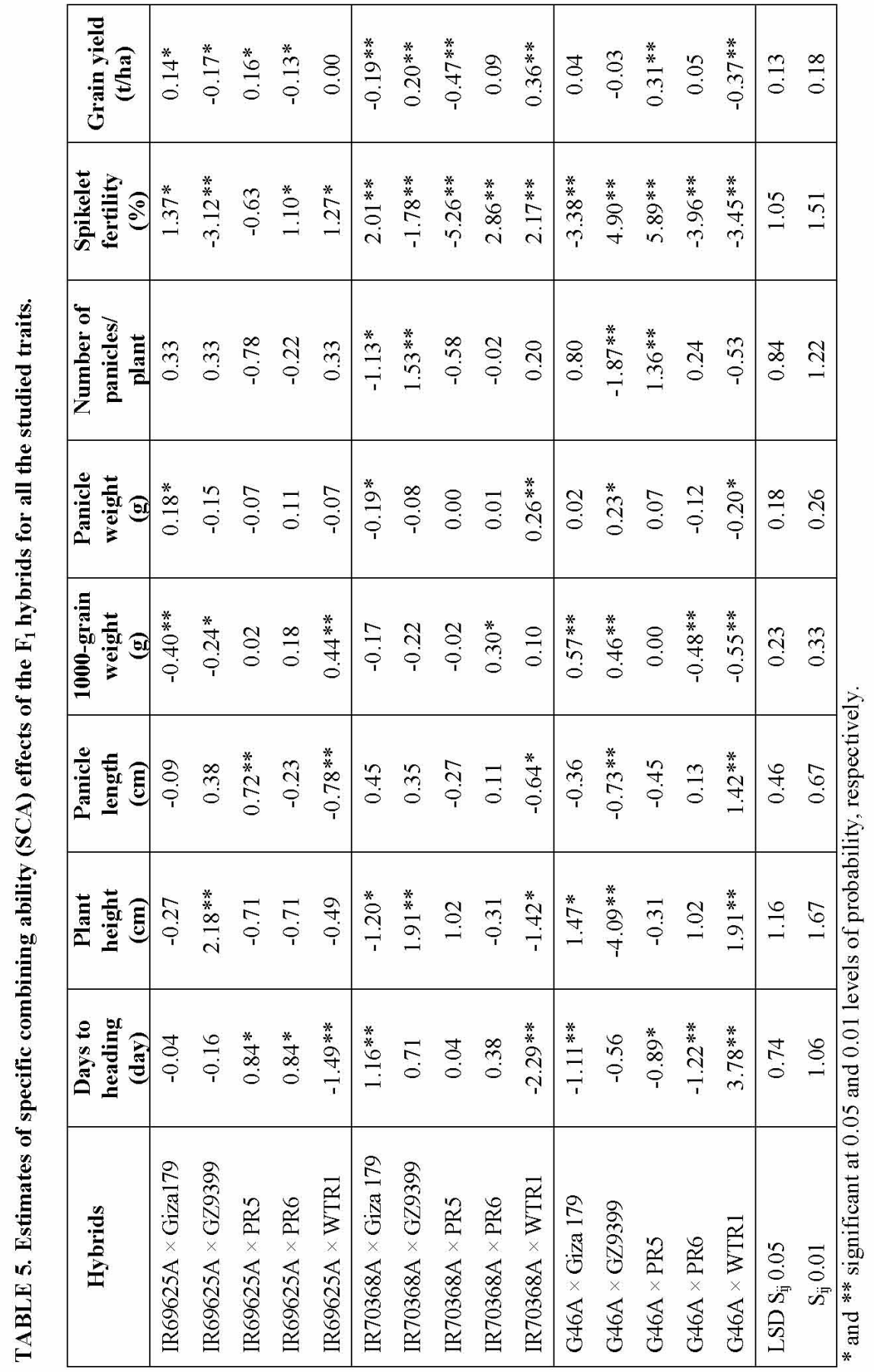

Egypt. J. Agron. 38, No. 2 (2016) 


\section{Estimates of heterosis}

Heterosis over the better parent (heterobeltiosis) and over the check variety Giza 178 (standard heterosis or superiority) for all the studied characters are presented in Table 6 . Only one hybrid $(\mathrm{G} 46 \mathrm{~A} \times \mathrm{PR} 6)$ showed significant and negative (desirable) heterosis relative to the better parent for heading date. While, all the hybrids, except IR69625A $\times$ WTR1, IR70368A $\times$ WTR1, and G46A $\times$ WTR1 had significant or highly significant negative heterotic effects relative to the check variety Giza 178 for this trait. This suggested the possibility of developing early maturity hybrids from these cross combinations.

For plant height, none of the cross combinations showed negative (desirable) heterosis over the better parent and the check variety, except the cross G46A $\times$ GZ9399 which had highly significant negative heterosis over the check variety Giza178. This indicates the possibility of developing short stature hybrids from this cross. Concerning panicle length, 13 out of 15 crosses showed significant or highly significant positive heterosis relative to the better parent. Such estimates ranged from 3.63 to $16.37 \%$ for the crosses IR70368A $\times$ PR5 and G46A $\times$ WTR1, respectively. Meanwhile, all the crosses gave highly significant and positive superiority over the standard variety Giza 178 . The cross G46A $\times$ WTR1 recorded the highest value $(34.33 \%)$ followed by G46A $\times$ PR6 (23.18\%). Data presented in Table 6 revealed that only four crosses exhibited significant or highly significant positive heterotic effects as deviation from the better parent for 1000-grain weight. Such estimates were minimized in case of IR69625A $\times$ PR6 (1.42\%) and maximized in case of G46A $\times$ Giza 179 (2.53\%). Furthermore, all the studied crosses detected highly significant positive heterosis relative to the check variety Giza 178. Such estimates ranged from 31.55 to $44.66 \%$ for the crosses IR70368A $\times$ GZ9399 and IR69625A × WTR1, respectively.

Regarding to panicle weight, results showed that all crosses had positive and highly significant heterosis over better parent and the check variety Giza 178. The highest positive heterosis percentages were exhibited by the cross G46A $\times$ GZ9399 $(56.25 \%)$ over better parent and G46A $\times$ WTR1 $(91.11 \%)$ over the check variety. Seven crosses showed significant or highly significant positive heterobeltiosis for number of panicles/plant. The hybrid IR69625A $\times$ PR6 recorded the most favourable value $(26.76 \%)$ followed by IR69625A $\times$ WTR1 $(21.83 \%)$ and IR70368A $\times$ PR6 (20.66\%). On the other hand, four hybrids showed highly significant positive heterosis over the check variety Giza 178 for the same trait. The hybrid IR69625A $\times$ PR6 recorded the highest value $(8.87 \%)$ followed by IR70368A $\times$ PR6 (3.63\%). Only the two crosses G46A $\times$ GZ9399 and G46A×PR5 exhibited desirable and highly significant heterosis over the better parent for spikelet fertility percentage (6.47 and $2.86 \%$, respectively). While, twelve crosses showed highly significant positive heterosis, when it was measured as a deviation from the check variety Giza178. Regarding to grain yield, all the hybrids showed positive and highly significant heterosis over the better parent and the check variety Giza 178. The highest positive heterosis percentages were exhibited by the cross G46A×PR6 (34.65\% and 25.93\%) over better parent and check variety Giza 178, respectively. Significant heterobeltiosis and standard heterosis for grain and its components in rice have been reported by Li et al. (2002), Nuruzzaman et al. (2002), Alam et al. (2004), Malini et al. (2006) and Anis (2013).

Egypt. J. Agron. 38, No. 2 (2016) 


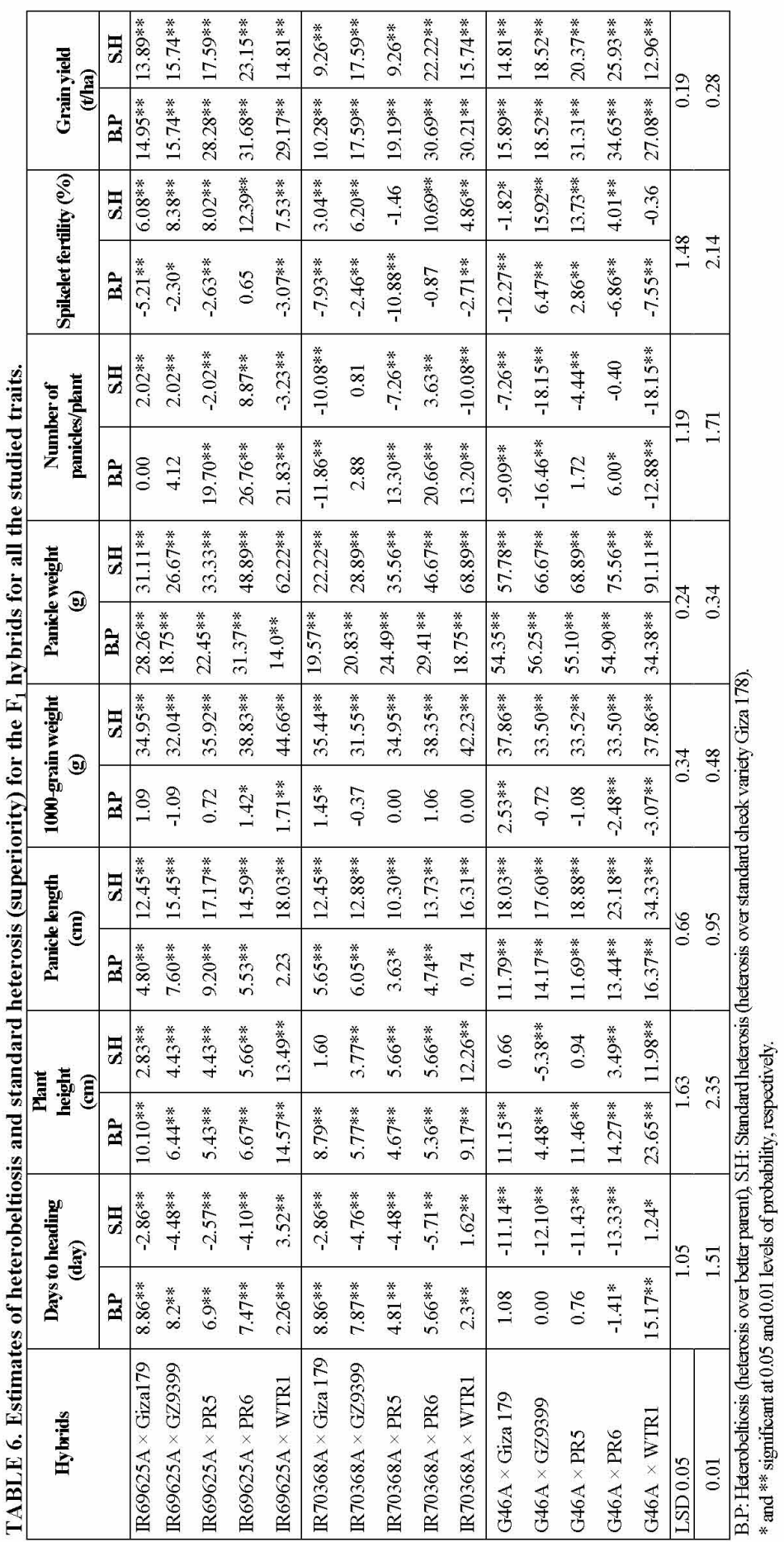

Egypt. J. Agron. 38, No. 2 (2016) 


\section{Estimates of genetic parameters}

Genetic variance components, heritability and contribution of the lines, testers and line $\times$ tester are presented in Table 7 . The results revealed that the dominance genetic variance $\left(\sigma^{2} \mathrm{D}\right)$ was greater than the additive genetic variance $\left(\sigma^{2} \mathrm{~A}\right)$ in controlled the inheritance of all the studied traits, except days to heading, plant height and panicle weight which was governed by the additive genetic variance. These results are in accordance with those of Abd El-Hadi et al. (2013) and Anis (2013). Heritability estimates in broad sense $\left(\mathrm{h}_{\mathrm{b}}^{2} \%\right)$ were high for all the studied traits. However, heritability estimates in the narrow sense $\left(\mathrm{h}_{\mathrm{n}}^{2} \%\right)$ were relatively high for panicle weight $(81.58 \%)$ and days to heading $(67.37 \%)$ while, it was relatively moderate for plant height $(56.28 \%)$ and low for the remaining traits. Results in Table 7 showed that the expected genetic advance $(\Delta \mathrm{g} \%)$ from selection, as percentage of mean, ranged from 3.86 to $17.32 \%$ for 1000-grain weight and panicle weight, respectively. High heritability estimates coupled with high genetic advance were recorded only for panicle weight trait. It is evident from Table 7 that the testers played important role towards days to heading $(51.95 \%)$, plant height $(76.75 \%), 1000$-grain weight $(73.08 \%)$ and grain yield $(55.44 \%)$, indicating predominant of paternal effects shown by testers for these traits. On the contrary, the contributions of the lines were higher than the contribution of the testers for panicle length (48.67\%), panicle weight $(53.19 \%)$ and number of panicles/plant $(38.89 \%)$. The contribution of line $\times$ tester interaction was important for spikelet fertility \% (59.12\%) only. These results are in agreement with those obtained by Abd El-Hadi et al. (2013) and Hasan et al. (2015).

TABLE 7. Estimates of genetic parameters for all the studied traits .

\begin{tabular}{|c|c|c|c|c|c|c|c|c|}
\hline \multirow{2}{*}{ Genotypes } & \multicolumn{8}{|c|}{ Studied traits } \\
\hline & $\begin{array}{c}\text { DH } \\
\text { (day) }\end{array}$ & $\begin{array}{c}\text { PH } \\
\text { (cm) }\end{array}$ & $\begin{array}{l}\text { PL } \\
(\mathbf{c m})\end{array}$ & $\begin{array}{c}\text { 1000- } \\
\text { GW } \\
\text { (g) }\end{array}$ & $\begin{array}{c}\text { PW } \\
\text { (g) }\end{array}$ & NPP & SF \% & $\underset{\text { (t/ha) }}{\text { GY }}$ \\
\hline Additive variance $\left(\sigma^{2} \mathrm{~A}\right)$ & 8.28 & 7.33 & 0.41 & 0.13 & 0.27 & 0.76 & 0.70 & 0.05 \\
\hline Dominant variance $\left(\sigma^{2} \mathrm{D}\right)$ & 3.43 & 4.27 & 0.55 & 0.19 & 0.03 & 1.16 & 19.63 & 0.09 \\
\hline Environmental variance $\left(\sigma^{2} \mathrm{E}\right)$ & 0.58 & 1.42 & 0.23 & 0.06 & 0.03 & 0.75 & 1.17 & 0.02 \\
\hline Broad sense heritability $\mathrm{h}_{\mathrm{b}}^{2} \%$ & 95.30 & 89.10 & 80.97 & 84.93 & 89.34 & 71.83 & 94.55 & 89.13 \\
\hline Narrow sense heritability $\mathrm{h}_{\mathrm{n}}^{2} \%$ & 67.37 & 56.28 & 34.47 & 33.56 & 81.58 & 28.49 & 3.24 & 33.89 \\
\hline Genetic advance $(\Delta \mathrm{g})$ & 6.88 & 6.62 & 1.82 & 1.08 & 1.06 & 2.42 & 9.03 & 0.73 \\
\hline$(\Delta \mathrm{g}(\%$ of meaan $)$ & 6.93 & 6.08 & 6.88 & 3.86 & 17.32 & 10.52 & 10.24 & 6.33 \\
\hline Contribution of lines \% & 40.44 & 13.24 & 48.67 & 5.97 & 53.19 & 38.89 & 9.13 & 12.92 \\
\hline Contribution of testers \% & 51.95 & 76.75 & 31.68 & 73.08 & 44.38 & 38.75 & 31.75 & 65.65 \\
\hline Contribution of line $\times$ tester $\%$ & 7.11 & 10.01 & 19.66 & 20.95 & 2.43 & 22.36 & 59.12 & 21.43 \\
\hline
\end{tabular}

DH: Days to heading (day), PH: Plant height (cm), PL: Panicle length (cm), 1000-GW (g):1000-grain weight, PW: Panicle weight (g), NPP: No. of panicles/plant, SF\%: Spikelet fertility \% and GY: Grain yield (t/ha) 


\section{References}

Abd El-Hadi, A. H., Kash, K. S., El-Mowafi, H. F. and Anis, G. B. (2013) The utilization of cytoplasmic male sterile (CMS) and restorer lines in the developing of hybrid rice. J. Agric. Chem. and Biotechn., Mansoura Univ. 4 (7), 266-277.

Alam, M.F., Khan, M.R., Nuruzzaman, M., Parvez, S., Swaraz, A.M., Alam, I. and Ahsan, N. (2004) Genetic bases of heterosis and inbreeding depression in rice (Oryza sativa L.). J. Zhejiang Univ. Sci. 5 (4), 406-411.

Anis, G. B. (2013) Development and evaluation of new restorer and maintainer lines and their relationship to heterosis in rice. PhD. Thesis, Fac. of Agric. Mansoura Univ., Egypt.

Borton, G.W. and Devan, E.H. (1953) Estimating heritability in tall fescue (Festuca arundianacea) from replicated clonal material. Agron. J. 45, 478-481.

Cheng, S.H., Zhuang, J.Y., Fan, Y.Y., Du, J.H. and Cao, L.Y. (2007) Progress in research and development on hybrid rice: A super-domesticate in China. Annals of Botany, 100 (5), 959-966.

Dalvi, V. V. and Patel, D. V. (2009) Combining ability analysis for yield in hybrid rice. Oryza, 46 (2), 97-102.

El-Degwy, I. S. (2013) Genetic analysis of some cytoplasmic male sterile and suggested restorer rice lines. Egypt J. Agron. 35(1), 93-114.

Fageria, N.K. (2007) Yield physiology of rice. J. Plant Nutr. 30, 843-879.

Fonseca, S. and Patterson, F. L. (1968) Hybrid vigour in seven-parent diallel cross in common wheat (T. aestivum L.). Crop Sci. 2, 85-88.

Hasan, M.J., Kulsum, M.U., Hossain, E., Hossain, M. M. Rahman, M. M. and Rahmat, M. M. F. (2015) Combining ability analysis for identifying elite parents for heterotic rice hybrids. Academia Journal of Agricultural Research, 3(5), 70-75.

Hassan, H. M., Hammoud, S. A. A. El-Moghazy, A. M. and El-Abd, A. B. (2012) Combining ability and heterosis estimates from line $\times$ tester mating design under water stress conditions in rice (Oryza sativa L.). J. Plant Production, Mansoura Univ., 3 (12), $3117-3137$.

IRRI, (1996) "Standard Evaluation System for Rice". International Rice Research Institute (IRRI), P.O. Box 933, 1099 Manila, Philippines.

Johnson, H.W., Robinson, H.F. and Comstock (1955) Estimates of genetic and environmental variability in soybean. Agron. J. 47, 314-318.

Kempthorne, O. (1957) "An Introduction to Genetic Statistics". John Wiley and Sons Inc., New Yourk, U.S.A. 545pp.

Egypt. J. Agron. 38, No. 2 (2016) 
Li, W., Zhang, J. Z., Zhang, G. Q. and Zuo, Q. F. (2002) Analysis of heterosis of main agronomic traits in Indica-Japonica lines of rice. J. Southwest Agric. Univ. 24(4), 317-320.

Malini, N., Sundaram, T., Hari Ramakrishnan, S. and Saravanan, S. (2006) Prediction of hybrid vigour for yield attributes among synthesized hybrids in rice (Oryza sativa L.). Res. J. Agric. Biol. Sci. 2(4), 166-170.

Nuruzzaman, M., Alam, M. F., Ahmed, M. G., Shohael, A. M. , Biswas, M. K., Amin, M. R. and Hossain, M. M. (2002) Studies on parental variability and heterosis in Rice. Pakistan J. Biol. Sci. 5(10), 1006-1009.

Panwar, L. L. (2005) Line $\times$ tester of combining ability in rice (Oryza sativa, L.). Ind. J. Genet. 65(1), 51-52.

Petchiammal, K. I. and Kumar, C. R. A. (2007) Combining ability studies for yield and yield associated traits in rice (Oryza sativa L.) involving Assam rice cultivars. Int. J. Agric. Sci. 3(2), 234-236.

Rita, B. and Motiramani, N. K. (2005) Study on gene action and combining ability in rice. Oryza, 42(2), 153-155.

Rosamma, C.A. and Vijayakumar, N.K. (2005) Heterosis and combining ability in rice (Oryza sativa L.). Indian J. Genet. 65,119-120.

Saidaiah, P., Kumar, S. S. and Ramesha, M. S. (2010) Combining ability studies for development of new hybrids in rice over environments. J. Agric. Sci. 2(2), 225-233.

Saleem, M.Y., Mirza, J.I. and Haq, M.A. (2010) Combining ability analysis for yield and related traits in basmati rice (Oryza sativa L.). Pak. J. Bot. 42(1), 627-637.

Sandhyakishore, N., Ramesha, D., Reddy, M.S.T. and Hari Prasad, A.S. (2011) Combining ability analysis for identifying elite parents for heterotic rice hybrids. Oryza, 48, 101-107.

Sarker, U. (2001) Combining ability of CMS and restorer lines in rice (Oryza sativa L). MS Thesis. Bangabandhu Sheikh Mujibur Rahman Agricultural University, Salna, Gazipur, Bangladesh.

Satyanarayana, P.V., Reddy, M. S. S., Kumar, I. and Madhuri, J. (2000) Combining ability studies on yield and yield components in rice. Oryza, 37(1), 22-25.

Shyam, C.G., Chandrakar, P.K., Rastogi, N.K., Sharma, D. and Sarawgi, A. K. (2012) Combining ability analysis using CMS breeding system for developing hybrids in rice (Oryza sativa). Bangladesh J. Agril. Res. 37(4), 583-592.

Sreeramachandra, B.M., Satyanarayana, P.V., Madhuri, J. and Kumar, R.V. (2000) Combining ability analysis for identifying elite parents for heterotic rice hybrids. Oryza, 37, 19-22. 
Venkatesan, M., Anbuselvam, Y. Elangaimannan, R. and Karthikeyan, P. (2007) Combining ability for yield and physiological characters in rice. Crop Improvement, 44(4), 296-299.

Yuan, L.P. (2014) Development of hybrid rice to ensure food security. Rice Sci. 21,1-2

(Received 14/7/2016;

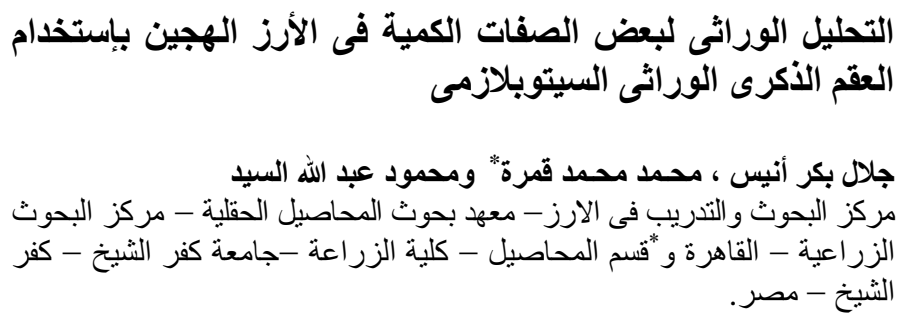

يهذف هذا البحث لار اسة مكونات التباين الور اثى، درجة التوريث، قوة الهجين و القدرة

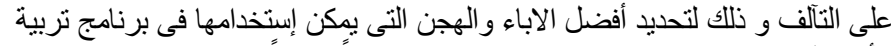

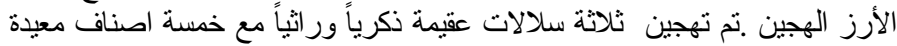

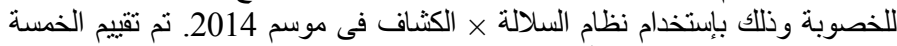

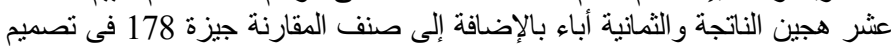

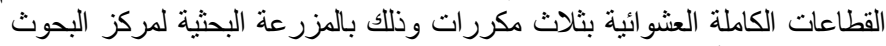

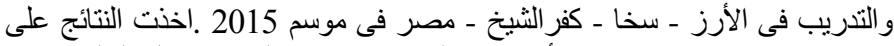

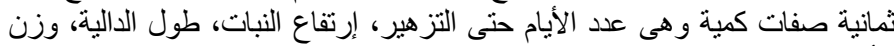

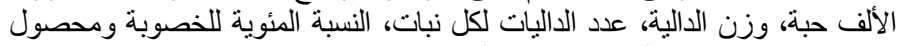

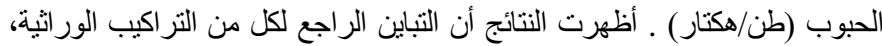

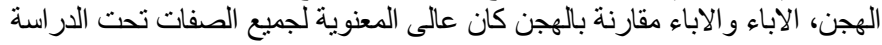

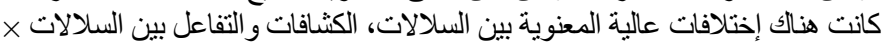

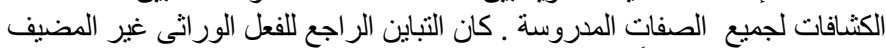

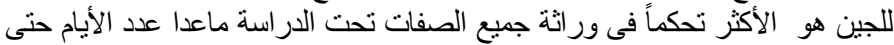

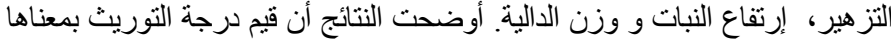

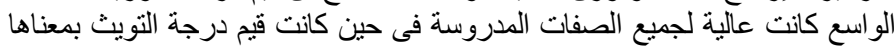

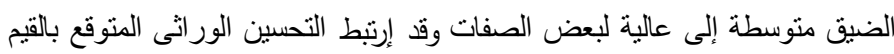

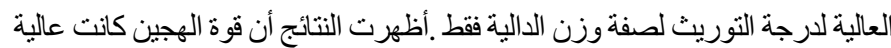

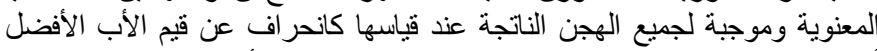

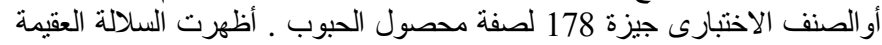

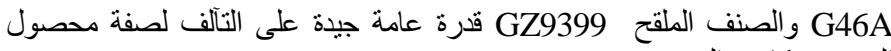

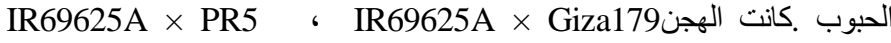
ه4 G46A × PR5 و IR70368A × WTR1، IR70368A × GZ9399، أفضل الهجن فى تأثيرات القدرة الخاصة على التآلف لصفة محصول الحبوب وبعض 